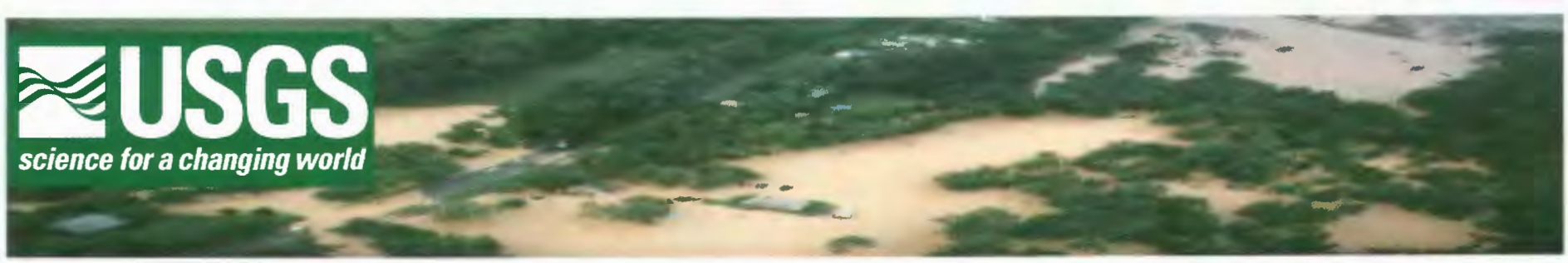

\title{
SPARTA, NEW JERSEY, FLOOD OF AUGUST 11-14, 2000
}

- More than 14 inches of rain fell in a small area of southeastern Sussex and northwestern Morris County in northwestern New Jersey during August 11-14, 2000.

- Flood peaks at some U.S. Geological Survey gaging stations on Lake Hopatcong, Musconetcong River, Green Pond Brook, Rockaway River, and Russia Brook tributary were the highest ever recorded.

- About 2,700 homes and businesses in Sussex, Morris, Warren, and Hunterdon Counties were flooded, and about 2,600 people were evacuated.

- Many bridges, dams, and roads were damaged or destroyed. Damage was estimated at \$179 million, and Sussex and Morris Counties were declared Federal disaster areas.

The U.S. Geological Survey (USGS), in cooperation with the Federal Emergency Management Agency (FEMA), conducted a study of the flood that occurred in the Sparta, New Jersey, area during August 11-14, 2000. This Fact Sheet documents precipitation amounts, peak flows and stages, indirect measurements of peak flow, and damage that resulted from the flood.

\section{Precipitation}

Unusually large amounts of rain produced by a series of thunderstorms deluged parts of northwestern New Jersey during the period August 11-14, 2000. Rainfall was greatest in parts of southeastern Sussex County and northwestern Morris County (fig. 1). More than 10 inches of rain fell in a limited area northwest of Berkshire Valley, east of Lake Hopatcong, north to eastern parts of Sparta Township and western parts of Jefferson Township. Doppler radar estimates of total rainfall for the 4-day period reached approximately 15 inches along the border between Sussex and Morris Counties (National Weather Service, 2000). A severe thunderstorm on August 12 resulted in approximately a 1,000-year event for total rainfall in a 6 -hour period (National Weather Service, 2000).

The areal extent of the greatest rainfall amounts was limited. Rainfall was greatest within a 10-mile radius of Sparta Township (table 1). The rain was most intense-2.5 inches per hour-during a 6-hour period on August 12 in the Sparta Mountain area. On that date, more than 12 inches of rain was recorded at the Morris Lake gage. Parts of Jefferson Township received nearly 40 percent of the average annual precipitation for northern New Jersey during the 4-day period. Rainfall during this event was four times the long-term average for the month of August in the Sparta area (National Oceanic and Atmospheric Administration, National Climatic Data Center, unpublished data accessed March 17, 2001, on the World Wide Web at URL ftp:// ftp.ncdc.noaa.gov/pub/data/cirs). Rainfall was greatest in the headwaters of the Wallkill, Musconetcong, and Rockaway River Basins.

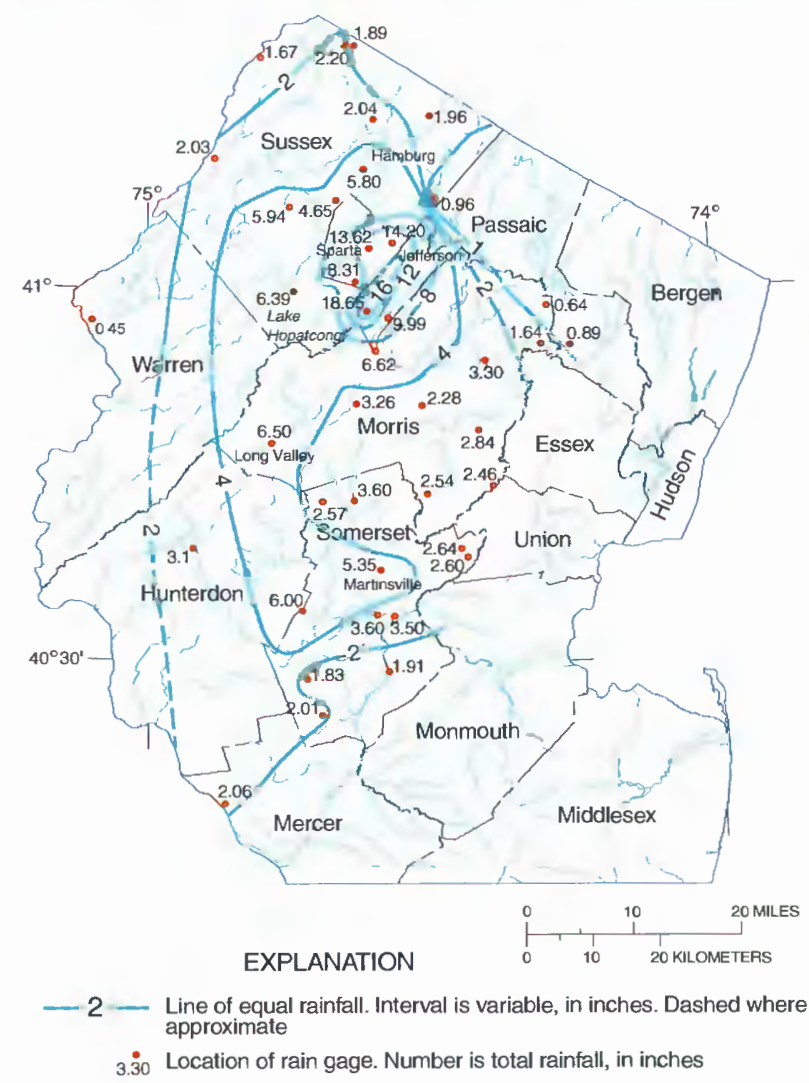

Figure 1. Total rainfall at 41 rain gages in northern New Jersey, August 11-14, 2000. (Data from Walter Nickelsburg, National Weather Service, written commun., 2000; Nicholas Stefano, Sussex County Weather Network, written commun., 2001; William Grinelli, Town of Newton, written commun., 2000; and unpublished data, U.S. Geological Survey, W. Trenton, N.J.)

Table 1. Total precipitation during August 11-14, 2000, at rain gages within approximately a 10 -mile radius of Sparta, N.J. [Data from Clark Gilman, N.J. Department of Environmental Protection, written commun., 2000; Nicholas Stefano, Sussex County Weather Network, written commun., 2001; William Grinelli, Town of Newton, written commun., 2000]

\begin{tabular}{|c|c|c|}
\hline \multicolumn{2}{|c|}{ Rain-gage location } & \multirow{2}{*}{$\begin{array}{l}\text { Total precipitation } \\
\text { (inches) }\end{array}$} \\
\hline Locality & County & \\
\hline Andover & Sussex & 6.39 \\
\hline Berkshire Valley & Morris & 9.99 \\
\hline Canistear & Sussex & .96 \\
\hline Hamburg & Sussex & 5.80 \\
\hline Jefferson Township & Morris & 18.6 \\
\hline Lafayette & Sussex & 4.65 \\
\hline Morris Lake & Sussex & 13.6 \\
\hline Newton & Sussex & 5.94 \\
\hline Sparta & Sussex & 8.31 \\
\hline Sparta Mountain & Sussex & 14.1 \\
\hline West Wharton & Morris & 6.62 \\
\hline
\end{tabular}




\section{Peak Flows and Stages}

Peak flows at 35 established USGS gaging stations in northwestern New Jersey ranged from less than 2-year to greater than 100-year events, reflecting the limited areal extent of the greatest rainfall amounts and the large variation in rainfall across the area. Peak flows recorded at the USGS gages on Lake Hopatcong (01455400), Musconetcong River (01455500), Green Pond Brook (01379780), Rockaway River (01379700), and Russia Brook tributary (01379630) were the highest ever recorded (table 2). These gages are located at sites that drain areas that received 10 or more inches of rain during August 1114. Peak flows on Lake Hopatcong and on the Musconetcong River just downstream from the lake exceeded those of a 100 year flood (fig. 2). The Rockaway River at Berkshire Valley (01379700) experienced a 40-year flood, and the gage on the Lamington River at Succasunna (01399190) recorded a peak flow equal to that of a 12-year flood. The runoff from the headwaters of these basins was attenuated by the time it reached the downstream stations. In contrast, the gages on Green Pond Brook recorded peaks equal to those of 3- to 6-year floods, with peaks increasing with distance downstream. Recurrence intervals of peak flows at other USGS gaging stations in the area were less than 10 years, and many were less than 2 years.

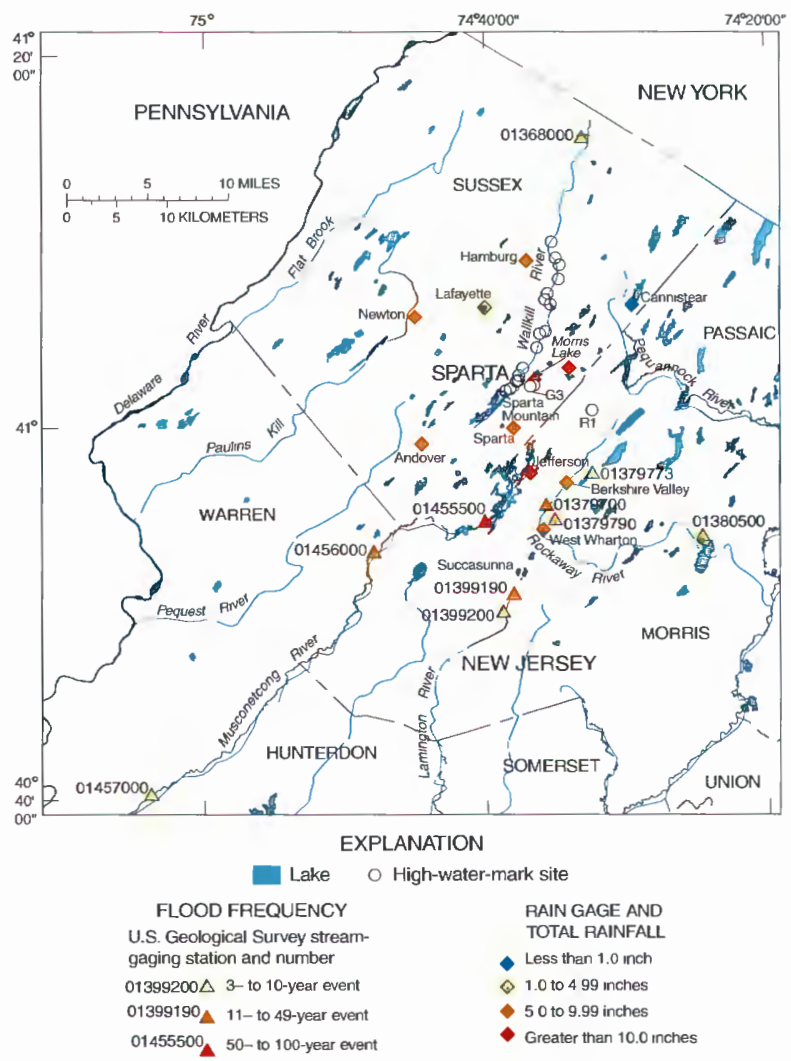

Figure 2. High-water-mark sites, flood frequency at U.S. Geological Survey gaging stations experiencing a flood event with a recurrence interval greater than 2 years, and total rainfall at rain gages within a 10 -mile radius of Sparta, N.J.

As part of the USGS study of this flood, peak stages were measured at 21 stream sites along the Wallkill River, Glen Brook, and Russia Brook tributary, where no active USGS gaging stations are present (fig. 2). Peak stages at most of the study sites surveyed along the Wallkill River from Sparta downstream to Hamburg and at Russia Brook tributary at Milton (13 of the 18 locations studied on these streams) equaled or exceeded the 500-year flood elevation (a flood elevation with a 0.2 -percent chance of occurring in any given year) as published by FEMA (Federal Emergency Management Agency, 1983a,

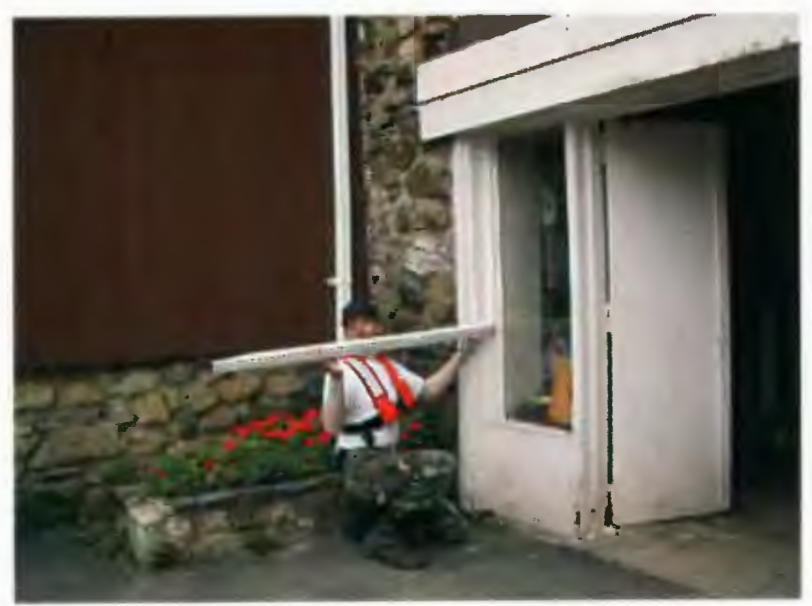

Figure 3. Photograph of high-water mark on the Culligan Building near the Station Road bridge upstream from Glen Brook in Sparta Township, N.J.

1983b, 1983c, 1983d, 1984a, 1984b). High-water marks were more than $3 \mathrm{ft}$ (feet) above land surface at some buildings near these sites (fig. 3). Peak stages equaled or exceeded the 100 -year flood elevation (a flood elevation with a 1-percent chance of occurring in any given year) at four sites. Because flood flows were attenuated with distance downstream, the peak stage at the most downstream site, Wallkill River near Unionville, N.Y. $(01368000$, site W16), was equal to the elevation of a flood with a 3-year recurrence interval. Because no FEMA flood-insurance studies were conducted along Glen Brook, no flood-profile elevations are available for this stream.

\section{Indirect Measurements of Peak Flow at Selected Sites}

Indirect measurements of peak flow were computed at Russia Brook tributary at Milton (site R1) and at Glen Brook near Sparta (site G3) (fig. 2). Glen Brook near Sparta is located in Sparta Glen 0.3 mile downstream from Morris Lake. Some of the worst damage from the flood occurred along Glen Brook. All three major bridges that cross this stream were washed out, stranding residents in some neighborhoods. A peak flow of $2,520 \mathrm{ft}^{3} / \mathrm{s}$ (cubic feet per second) through a 200 - $\mathrm{ft}$ stream reach was computed by use of the slope-area method (Dalrymple and Benson, 1967). The drainage area at the downstream end of the reach is $3.68 \mathrm{mi}^{2}$ (square miles); therefore peak runoff was $685 \mathrm{ft}^{3} / \mathrm{s} / \mathrm{mi}^{2}$. This is the highest runoff computed for any site during this flood (fig. 4).

Russia Brook tributary near Milton (site R1) is located at the site of a discontinued USGS gaging station. The slope-area method was used to compute the peak flow through a $180-\mathrm{ft}$ 
Table 2. Historical flood peaks and flood peaks during the August 12-14, 2000, flood at U.S. Geological Survey gages in northwestern New Jersey where the recurrence interval of the peak flow was greater than 2 years

[NA, not available; 13 of 35 sites in the region experienced a flood with a frequency greater than 2 years; mi $^{2}$, square miles; $>$, greater than; $\mathrm{ft}$, feet; $\mathrm{ft}^{3} / \mathrm{s}$, cubic feet per second; $\mathrm{ft}^{3} / \mathrm{s} / \mathrm{mi}^{2}$, cubic feet per second per square mile]

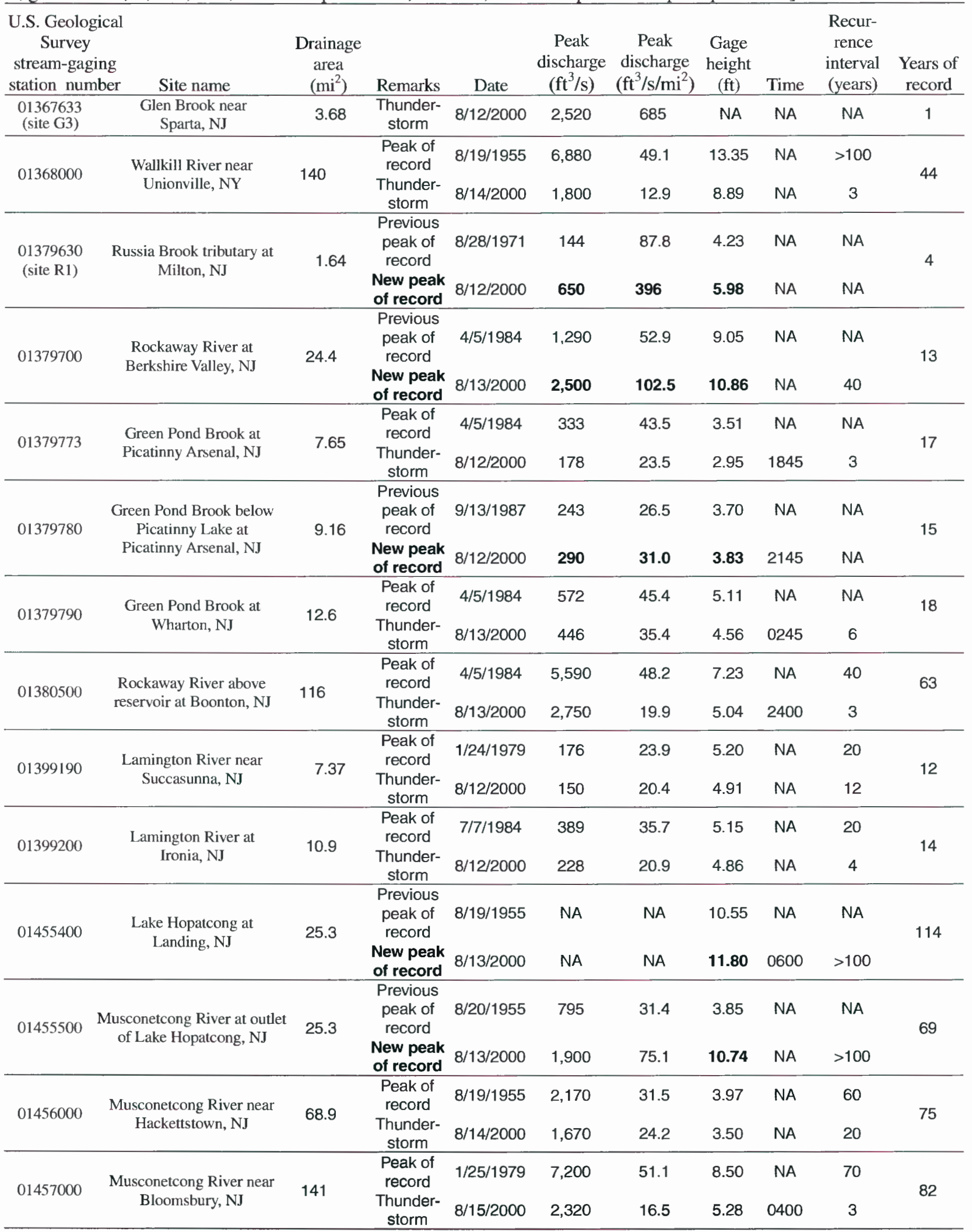




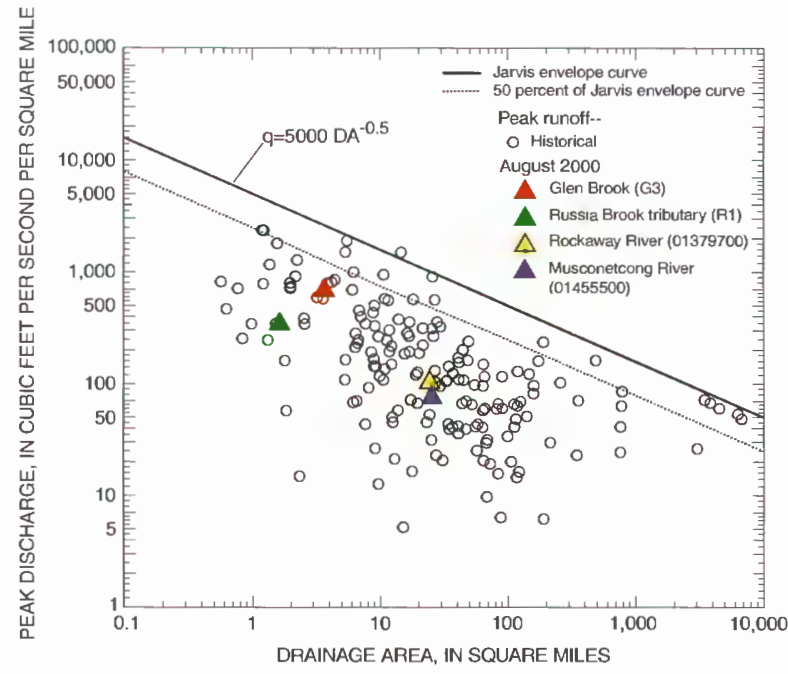

Figure 4. Historical peak unit-runoff values at selected U.S. Geological Survey streamflow-gaging stations in northwestern New Jersey and the four highest peak unitrunoff values measured during August 12-14, 2000. (DA, drainage area; q, peak flow per square mile)

stream reach beginning $50 \mathrm{ft}$ below the gage house. A peak flow of $650 \mathrm{ft}^{3} / \mathrm{s}$ was computed for this site; therefore, peak runoff was $396 \mathrm{ft}^{3} / \mathrm{s} / \mathrm{mi}^{2}$ (fig. 4). This value is the second highest runoff computed for this event.

\section{Flood Damage}

About 2,700 homes and businesses in southeastern Sussex, western Morris, and parts of Warren and Hunterdon Counties along the Musconetcong River were flooded. Eight houses were destroyed and about 100 suffered major damage (National Weather Service, 2000). About 2,600 people in Morris, Sussex, and Hunterdon Counties were evacuated. The dams on Seneca Lake, Tomahawk Lake, Furnace Pond, and Edison Pond in Sussex County were completely destroyed. An additional 26 dams in Sussex and Morris Counties were damaged (National Weather Service, 2000). Three bridges were destroyed and eight others were damaged or closed. Parts of 3 roads were washed away, 24 were damaged, and countless others were closed. Damage was estimated at $\$ 179$ million (National Weather Service, 2000). President Clinton declared Morris and Sussex Counties a Federal disaster area on August 16.

Flooding was most severe in the headwaters of the Wallkill River Basin. A state of emergency was declared on August 14 in Sparta, where properties along Glen Brook and other small tributaries to the Wallkill River experienced some of the worst damage from the flooding. Bridges in Sparta and Ogdensburg collapsed, leaving many motorists and entire neighborhoods stranded. All three major bridges that cross Glen Brook were washed out during the flood, stranding residents in some neighborhoods. Governor Whitman dispatched National Guard troops to help emergency crews reach flooded neighborhoods.

--Robert G. Reiser and Robert D. Schopp

\section{References Cited}

Dalrymple, Tate, and Benson, M.A., 1967, Measurement of peak discharge by the slope-area method: U.S. Geological Survey Techniques of Water-Resources Investigations, book 3, chap. A2, 12 p.

Federal Emergency Management Agency, 1983a, Flood insurance study, Township of Jefferson, Sussex County, New Jersey: Federal Emergency Management Agency, Federal Insurance Administration, January 1983, 23 p.

Federal Emergency Management Agency, 1983b, Flood insurance study, Township of Wantage, Sussex County, New Jersey: Federal Emergency Management Agency, Federal Insurance Administration, August 1983, 14 p.

Federal Emergency Management Agency, 1983c, Flood insurance study, Borough of Franklin, Sussex County, New Jersey: Federal Emergency Management Agency, Federal Insurance Administration, September 1983, 14 p.

Federal Emergency Management Agency, 1983d, Flood insurance study, Borough of Hamburg, Sussex County, New Jersey: Federal Emergency Management Agency, Federal Insurance Administration, September 1983, 14 p.

Federal Emergency Management Agency, 1984a, Flood insurance study, Borough of Ogdensburg, Sussex County, New Jersey: Federal Emergency Management Agency, Federal Insurance Administration, March 1984, 14 p.

Federal Emergency Management Agency, 1984b, Flood insurance study, Township of Sparta, Sussex County, New Jersey: Federal Emergency Management Agency, Federal Insurance Administration, April 1984, 17 p.

National Weather Service, 2000, Storm data and unusual weather phenomena, August 2000, New Jersey report. (Accessed January 3, 2001, on the World Wide Web at URL http:// www.ncdc.noaa.gov/pdfs/sd/sd.html).

\section{For additional information contact: District Chief U.S. Geological Survey 810 Bear Tavern Road, Suite 206 West Trenton, New Jersey 08628 email: dc_nj@usgs.gov}

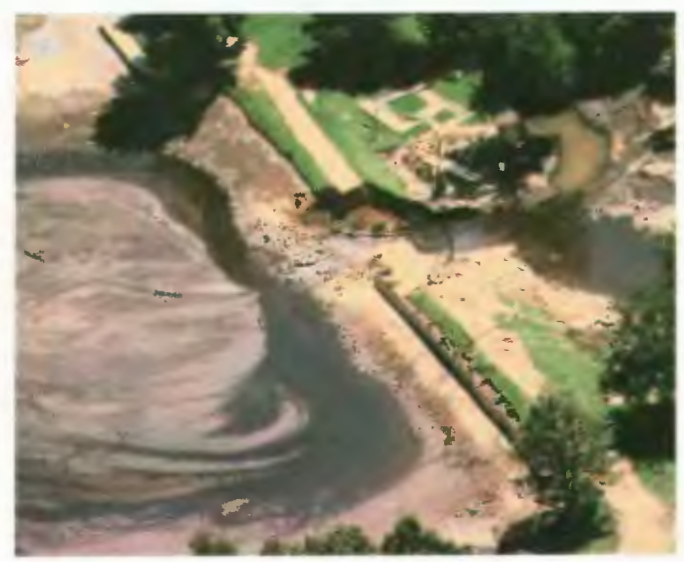

Aerial photograph of Tomahawk Lake on Lubbers Run in the headwaters of the Musconetcong River Basin, August 12, 2000. (Photograph taken by Joyce Bambuch, Division of Emergency Management, Sussex County Sheriff's Department, Sussex County, N.J.) 